period, but if it is short many revolutions must be watched. These stars proceed more quickly from minimum to maximum than from maximum to minimum, and this is also the case with new stars. At last it is found that the colour is most monochromatic nearest the minimum. The brightness of the comparison stars is best obtained from their comparison with the variable and become therefore better known the more revolutions are watched. The final discussion will sometimes show that one or more of the comparison stars are variable themselves, for astronomers agree that there are many more variable stars in the sky than those contained in the catalogues.

As to the physical explanation of these phenomena we do not learn much from Argelander, who was one of the last champions of the old school. It is even said about him that he to the last stuck to Herschel's theory of the structure of the sun in spite of this being opposed to Newton's axioms, and framed, according to the now obsolete assumption, that every heavenly body ought somehow to furnish a comfortable abode for beings like ourselves. We can only comprehend unknown things from what is already known to us, and it is therefore rational to suppose variable stars analogous to our sun, whose lustre must vary with the extent of its spots. It is no doubt reserved to the spectroscope to settle the question, meantime we can only keep in view Hind's important remark that variable stars are often of a ruddy colour, and appear surrounded by nebulosity at their minimum. W. D.

\section{COFFEE-LEAF DISEASE OF CEYLON AND SOUTHERN INDIA}

I. FISTORICAL REMARKS.-During the last ten years, the coffee plantations of Ceylon and Southern India have had to contend with a disease which has seriously affected their productiveness and entailed a heavy loss upon the proprietors. This disease, Hemileia vastatrix, popularly known as the coffee-leaf disease, was first observed in May, 1869 , on a few plants in Madulsima, a newlyopened coffee district in the south-west of Ceylon, bordering on the low country. In July following, two or three acres were attacked, and from that time the disease has gradually spread, till, in 1873 all, or nearly all, the estates in the island were attacked by it. On the appearance of the disease in 1869 , the distinguished fungologist, the Rev. M. J. Berkeley, determined its true character, and described it in the Gardener's Chronicle for I 869 (p. I, I 57 , with woodcut). It was found to be a fungus allied to the moulds, and named Hemileia vastatrix, B. and Br. It was subsequently described in the Fournal of the Linnean Society ("Botany," vol. xiv. p. 93, pl. 3, Fig. Io), and a short notice appeared in the Quarterly Fournal of Microscopical Science, 1873, pp. 79-81. In 1876 Dr. M. C. Cooke described and figured the disease from Indian specimens in the India Museum Report, I876, pp. 4-6. More recently the Rev. R. Abbay, who, during several years residence in Ceylon, made this disease an objeci of special study, gave a fuller description of it, with the results of his observations upon the germination of the spores and their growth under artificial cultivation, in the Fournal of the Linnean Society, 1878 ("Botany," vol. xvii. pp. 173-184, pl. I 3 and 14 ).

In his first notice of the disease the Rev. M. J. Berkeley speaks of it as a "minute fungus which has caused some consternation amongst the coffee planters of Ceylon in consequence of the rapid progress it seems to be making amongst the coffee plants." He further remarks : "It is not only quite new, but with difficulty referable to any recognised section of fungi. Indeed, it seems just intermediate between true mould and Uredos, allied on the one hand to Trichobasis, and on the other to Rhinotrichum. Though the fungus is developed from the parenchyma of the leaf, there is not any covering to the little heaps, such as is so obvious in Uredo and its immediate allies, while the mode of attachment reminds one of Rhinotrichum ", At that time no other form of Hemileic was known, and it was supposed to stand alone as the only species, and to be indigenous to Ceylon. Since then, another species of Hemileia, viz., $H$. canthii, B. and Br., has been found on a Ceylon jungle tree, Canthium campanulatum, ${ }^{1}$ and lately Dr. Cooke appears to have met with a third species from Southern Africa.

Writing in 1874, Dr. Thwaites, the distinguished Director of the Botanic Gardens, Ceylon, describes the Hemeleia vastatrix as " a parasitic growth within the coffee tree of a well-defined species of fungus, originated and reproduced by means of spores, easily distinguished from every other known fungus." "There can be no question," he continues, "that this fungus is communicated from coffee plant to coffee plant through the dissemination of its spores, and that these may be conveyed by the wind, or by streams of water, or by animals of any kind moving from place to place." Though at first it was believed that some elements of the fungus were present "in the growing tissues of the coffee plant in a diffused form," this view was afterwards abandoned, further microscopical investigations having proved that the disease was mainly external, and "that the coffee tree suffered rather from exhaustion than from the poisoning of its juices." During 1873 and 1874 investigations of an important character were carried on by Dr. Thwaites and the Rev. R. Abbay, which led them to the conclusion that when grown upon charcoal kept constantly moist, the orangecoloured spores representing the fruit of the disease, gave rise to filaments more or less branched. At the termination of the branches "secondary spores appear to have been produced in the form of radiating necklace-shaped strings of little spherical bodies of uniform size, closely resembling the fructification of an Aspergillus."

2. Effects produced.-The effects of the fungus upon the coffee trees would seem to be the gradual loss of vital energy caused by repeated destruction of the leaves. The tree after the first attack of the disease, which is often apparently the most severe, throws out fresh, healthy-looking leaves, and exhibits for a certain period the appearance of having perfectly recovered. These fresh leaves, however, after the expiration of a few months, exhibit the characteristic spotting, and are sooner or later covered, on the under side, by orange-coloured dust representing the spores of the disease, and, as in the previous attack, fall prematurely. These repeated attacks at length seriously affect the health of the tree, which, if old and ill-cultivated, becomes of little or no value as a cropproducer.

The rapidity with which the disease was propagated after its first appearance, may be realised from the fact that although it was noticed only in one locality in May, 1869, it quickly spread to the neighbouring coffee-districts, and especially among native coffee, till in 1873 it was spoken of "as being found in nearly all, if not all, the estates in the island." The disease appears to have been noticed in India in 1869 and 1870 , almost simultaneously with its appearance in Ceylon. ${ }^{2}$ In February, 1874, its presence was seriously felt in Tellicherry, and it appears to have spread generally through the Wynaad and Mysore districts, and its first effects were so severe that it threatened to give a considerable check to coffee enterprise in Southern India. ${ }^{3}$ In 1876 the disease appeared in Sumatra, and this year it has been found in the plantations of Java and Bencoolen; there can be little doubt, therefore, that the Hemileia is destined to be a wide-spreading and prevalent enemy in all coffee-producing areas of the East Indies.

The effects of the leaf-disease upon the exportation of

$$
\begin{aligned}
& \text { I "Enum. Plant. Zeylan. Rubiacea," p. } 153 . \\
& 2 \text { Report of India Museum, M. C. Cooke, } 1876 . \\
& 3 \text { Gardener's Chronicle, February, } 1874 .
\end{aligned}
$$


coffee from Ceylon, may be very distinctly traced. In 1869-70, before the disease had appeared generally upon the coffee plantations, Ceylon exported $1,009,206$ cwts. of coffee, consisting of 860,707 cwts. plantation coffee, and 148,499 cwts. native coffee. In $1876-77$, when there were 52,000 more acres in bearing, the total exports were only 797,763 cwts., viz., 727,420 cwts. plantation coffee, and So, 343 cwts. native coffee. ${ }^{1}$

The yield of native coffee ${ }^{2}$ has been steadily declining since 1868 , owing to the want of high cultivation and manuring which have, in some measure, at least, saved the plantation coffee from being subject to the full influences of the disease. The culmination of crop and total value for native coffee was reached in 1868 , the year before the leaf disease appeared, when $218,584 \mathrm{cwt}$. were exported. In 1877 the export of native coffee had fallen to $76,182 \mathrm{cwts}$., only a little over a third of what it was in $1868 .^{3}$ The influence of the disease has also seriously reduced the yield per acre. The Rev. R. Abbay, in the paper mentioned above, states that "Previous to and including I 87 I the average yield for five years over the whole island had been $4.5 \mathrm{cwt}$. per acre, whilst for the five succeeding years the average has only been $2.9 \mathrm{cwt}$. a decrease in the production of somewhat more than one-third." 4

The deficiency in value of crop has been variously estimated; "the average annual deficiency in the whole island has been estimated by some as at least $2,000,000 l$. Since the 'disease' made its appearance in 1869, the coffee enterprise has suffered to the extent of from $12,000,000 l$. to $15,000,000 l$. in crops alone." 5 A portion of the loss which the coffee estates have suffered may be and is, no doubt, due to exceptionally unfavourable seasons for the blossoming and development of fruit, and to the fact that many unsuitable areas were planted with coffee, which have since become unproductive; but there is a marked difference in the uniform succession of crops and in the yield per acre since $187 \mathrm{I}$, even in the best coffee districts, which is evidently attributable to the action of the coffee-leaf disease.

When the trees are severely attacked by "disease," there is a premature fall of leaf and a check to the growth, which invariably results in a partial loss of crop. The trees also appear much thinner than formerly, having a wiry, cickly look, and do not make new wood so rapidly. As the disease shows itself mostly in dry weather, and just before the crop is ripening, its effect upon the trees is more severe and lasting than it otherwise would be ; the tips of the branches often die back, involving, as the tree does not ripen all the berries, a great percentage of light coffee and black-hearted beans. The vitality of the trees being thus yearly weakened, there is often a failure of blossom even in what may be called favourable seasons, for though the blossom is forced out, it finds insufficient food-supply to support it, and, consequently, a large and wonderful show of blossom often ends in a total or partial failure of crop.

It appears that during the earlier years of its ravages the disease, after a very severe attack, would so completely disappear, and the trees, relieved from its enfeebling effects, would put forth such an abundant supply of new wood and foliage that it was confidently hoped that it was only a passing visitation, and that it would soon and entirely pass away. Even now its attacks are often confined for some time to certain districts, and even to certain parts of estates, but it seems to be seldom absent from patches of old and ill-cultivated coffee, and from native gardens. It soon, however, became evident, in spite of its fugitive character, that though the disease did not completely kill any trees, its accumulative effects

$x$ "Ferguson's Directory of Ceylon," $x 876-78$. Introd.

Unpruned coffee grows with little or no cultivation in Sinhalese gardens. 3 The falling off in native coffee is possibly not quite so much as these figures would indicate, for latterly an increasing quantity of native garden

parchment is shipped as plantation coffee. ufon them, and especially on the older trees, were such that they could not be depended upon to ripen their crop or to produce, except in alternating periods, a moderately average crop. In 1874 Dr. Thwaites reported that "there is great reason to believe, from what has been observed, that high cultivation, with judicious manuring, enables the tree to better sustain the attacks of the fungus, and to retain strength and vigour enough to produce a fair yield of berry." Encouraged by this opinion, planters adopted manuring operations generally, not as a cure for leaf disease, but in order to strengthen the trees and enable them the better to bear the double strain induced by crop and leaf disease. Though to some extent successful, it was noticed that, with the leaf disease present, the effects of manuring were not nearly so lasting as formerly, and were seldom apparent after the first or second year. There was also a less ready response on the part of the trees, and cases were not infrequent where trees had almost died out when forced to produce heavy crops, and others, where trees in a large degree had ceased. to yield to any stimulus whatever.

3. Remedial Measures.-From what has been already mentioned it may naturally be supposed that the coffeeleaf disease and its effect on coffee cultivation in the East have occupied considerable attention during the last ten years, and, indeed, it may be looked upon as the most pressing and momentous of all questions affecting the prosperity and welfare of Ceylon, which depends so largelyr upon its coffee enterprise. Many suggestions have been made from time to time with regard to the application of suitable and effective remedies. As early as 1869 the Rev. M. J. Berkeley recommended the use of flowers of sulphur, or "one of the sulphurous solutions recommended. for the extirpation of the hop-mildew," but the fugitive and deceptive nature of the disease and the vast area. (over 200,000 acres) to be treated prevented any decided steps being then taken.

The hopes that were entertained respecting the temporary nature of the visitation and its possible mitigation. by the application of suitable manures also led planters to look to indirect rather than direct means for checking the ravages of the disease. A few experiments were initiated, but from an imperfect knowledge of the disease and want of suitable apparatus no satisfactory results. were obtained.

In January of this year a series of systematic experiments were initiated at Wallaha Estate, Lindula, in conjunction with the Hon. G. A. Talbot. In these experiments advantage was taken of the fact that the disease in its first or filamentous stage appears to exist as an external parasite upon the leaves and branches. It was found experimentally that an application of flowers of sulphur arid coral lime entirely destroyed these external mycelial threads and without inflicting the slightest injury even to the most delicate parts of the plant.

This fact fully established, and being confirmed by subsequent experiments on larger areas, gave an entirely new aspect to the subject, and the present year has been. signalised by an earnest and it is to be hoped a successful. attempt to reduce the ravages of the coffee-leaf disease.

As sulphur had been used so extensively and so successfully against fungoid parasites in other parts of the world it may appear a matter of surprise that no steps had been. taken long before this to test its efficacy on the coffee plant. In order to treat this disease successfully, how ever, it appears to be indispensable to carefully watch its. various stages and apply specifics only when the disease is mostly external. During several months of the year, especially during a continuance of wet weather, the vegetative system of the Hemileia seems mostly to be developed, and as the mycelial threads are present externally upon the branches and leaves, it offers a favourable means for being treated.

Unfortunately the disease during this stage is entirely. 
microscopical, and it requires very close observation even with the microscope to detect it. It is no wonder, therefore, that planters found it most difficult to decide when and how to apply remedies, and these considerations, rogether with others incidental to coffee cultivation, rendered a successful treatment, without scientific aid, both difficult and laborious.

When the results of the first experiments at Wallaha were published, the importance of the subject led the Colonial Government to take up further investigations, and to render special scientific aid to the planters in conducting their experiments. Experiments were organised on a large scale, and carried on in various districts throughout the island.

Meetings were also held, in which the development of the disease, and the results of more extended experiments and observations were given in detail.

As a result of this combined activity, a series of reports has lately been presented to the Legislative Council of Ceylon, embodying the results of the "Leaf-disease Inquiry;" these are published in the Sessional papers of this year. The results of the investigations, so far, are briefly summed up as follows:-

I. That the coffee-leaf disease is an organised fungoid growth, present on the estates in some form or other all the year round.

2. That in December and the early part of the year it is generally present as an external parasite upon the coffee trees, in the form of long filamentous threads which cover every part of the bark and leaves.

3. That while an external parasite and in the filamentous stage it is possible to destroy it most effectually, and by so doing to save the trees from the attacks of the fungus for at least one year.

4. That a mixture of sulphur and lime dusted by hand into the tree in the proportions of one of sulphur to two of lime has been found by experiment to be the most effective and suitable remedy which can be applied.

5. 'That the cost of the materials, at present prices in Colombo, together with the cost of application, will not exceed at the rate of $\mathrm{R} \times 6-50$ per acre.

6 . That the application of sulphur and lime in the proportions recommended, by releasing the trees from a heavy drain $u$-on their resources and restoring them to their nat:ral condition, will be attended by a much more profitable result than any expenditure upon artificial manures.

7. That in order to assist the means used for checking the lcaf disease it is most important that planters unite in the application of remedies and that they remove at once ail sickly trees on their estates and those not likely to be crop producers, and prevent by every means in their power the re-infection of good coffee.

8. That in order to secure perfect freedom from leafdisease it will no doubt be necessary to uproot all coffee trees on abandoned estates and old native gardens, and to take steps to prevent the disease from finding an asylum upon any plants not under careful cultivation. ${ }^{1}$

Judging by these results, which have been obtained by the united action of practical men of considerable knowledge and experience in coffee cultivation, aided by careful scientific observation, there is little doubt that the leaf disease can now be very effectually and conveniently treated, and if not completely exterminated, at least so materially reduced that it will not seriously injure the crops.

In the reports just quoted, great prominence is given to the necessity which exists for removing all old and sickly trees and up-rooting coffee plants growing without care or cultivation on abandoned estates and native gardens. Such trees appear to be the worst sufferers from leaf disease, and while they remain, are a continual source of danger to well-cultivated estates. One severely diseased

1 Morris's Reports on "Coffee-Leaf Disease," Sessional Papers, I, egisative Council of Ceylon, 1879 . tree is said to be sufficient to infect all trees in its immediate neighbourhood, and on that account a strong conviction is expressed in the Reports that little good can be expected from remedial measures of any kind, unless great care is taken to prevent the disease finding an asylum on "shuck" and abandoned coffee. The earnestness and intelligence which have characterised the action of the planters during the recent experiments lead to the hope that every means will be taken to check the development of the disease, and to increase the action of suit. able remedies. The Reports also recommend the extended cultivation of other plants, such as tea and cinchona, in order to break the continuity of the coffee estates and restrict the action of the disease as much as possible.

On thus reviewing the present condition of coffee cultivation in Ceylon, there is much that is hopeful and satisfactory. Dr. Thwaites in his Report dated March, I 877, remarks that "Notwithstanding the continued prevalence of Hemileia vastatrix upon the coffee plants throughout the island, there would appear to be little, if any, diminution in the anxiety to invest in the cultivation of coffee; the high prices obtained, and the beneficial effects of judicious manuring, are giving so much confidence to planters." This feeling appears still to be maintained, for keen competition and high prices characterise all recent sales of suitable forest land. And while this shows that coffee cultivation still possesses the confidence of investors in new districts, many estates even in the oldest districts, are sold at prices which show they possess great vitality, and that where careful and intelligent cultivation is pursued they still offer a promising and attractive investment. It is gratifying to find that the planters are now quite conscious of the true nature of the disease, and thoroughly aroused to the necessity which exists for treating it on the lines which have proved so eminently successful for the last twenty years "with the fungoid pests of the hop and vine.

By the extended cultivation of cinchona, tea, and other products, some of the conditions which have induced, or, at least, encouraged the ravages of the leaf-disease, will doubtless be removed, and in the renewed care and intelligence which are becoming daily more apparent in the methods of cultivation and the application of suitable manures, there is every reason to believe that coffee cultivation in Ceylon will be carried on under much more advantageous circumstances than at present, and while much that is now under coffee will probably be planted with tea and cinchona, the remaining lands will receive that due care and attention which cannot fail in time to restore the coffee estates of Ceylon to the position they have long held as one of the most successful and important of the enterprises of the East.

Kew, September 3

\section{OUR ASTRONOMICAL COLUMN}

THE SATELlites OF MARS. - In the Introduction to his Tables of the satellites of Uranus, Prof. Newcomb points out the advantage that might be derived, in systematic observations of the satellites by the preparation of a table showing the angles of position and distances corresponding to every $10^{\circ}$ in $u$ or the longitude of the satellite in its orbit, counted from the point in which it crosses the plane parallel to the earth's equator. From such a table the approximate positions of the satellites would be obtainable at any one opposition, with no further calculation than is required to determine the value of $u$ for the time of observation. The more rapid geocentric motion of the planet Mars does not of course allow of this principle of computation being applied so as to attain the same degree of approximation as in the case of Uranus, but even with Mars it is likely that such a table, prepared with the values of the various auxiliary quantities for the date of opposition November 12 , may facilitate observations, and we accordingly present one below :- 